\title{
Vertical integration, credit ratings and retail price settings in energy-only markets: navigating the Resource Adequacy problem
}

\author{
Paul Simshauser* \\ Level 22, 101 Miller Street \\ North Sydney, NSW, 2060. \\ Email psimshauser@agl.com.au
}

\begin{abstract}
Energy-only markets are prone to the Resource Adequacy problem, i.e. the timely entry of new plant. The reason for this is that competitive energy-only markets struggle to be remunerative given reliability constraints and market price caps. Historically, Australia's 45,000MW National Electricity Market has managed to navigate this well understood problem, albeit with government entities directly or indirectly responsible for a surprisingly large $73 \%$ of all new plant investments to 2007. But government involvement in direct investment has now ceased. So what will enable the industry to navigate the Resource Adequacy problem into the future? Quite simply, industrial organisation, the presence of firms with investment-grade credit ratings and setting any regulated retail prices or 'price to beat' with an LRMC floor.
\end{abstract}

Keywords: Resource Adequacy, Vertical Integration, Electricity Prices. JEL Codes: D24, D92, L11, L94 and Q41.

\section{Introduction}

Australia's 45,000MW National Electricity Market (NEM), which comprises the eastern and southern states of Australia, has long been acknowledged as one of the most successful microeconomic reforms of a power industry globally. ${ }^{1}$ But there are characteristics associated with the NEM's current institutional settings which represent risks to physical security of supply. These characteristics include a deregulated energy-only gross pool wholesale market, overlayed with regulated retail prices as the 'price to beat' in all but one region of the NEM. In academic literature, individually, these characteristics are well understood to present risks to future security of supply, but when combined they would seem to represent a particularly dangerous cocktail.

Despite the energy-only design of the market, Resource Adequacy, that is, the timely arrival of new plant to ensure ongoing reliability of supply, has historically been successfully navigated over the NEM's 11-year history, but hardly by good management. It has thus far been a story of an overcapitalised starting point, initial enthusiasm for deregulated investments quickly followed by the harsh financial reality of lumpy plant entry, and then the fortunate presence of government-owned businesses pre-emptively investing and finally, material changes to the reserve requirement calculation. But all of these otherwise relieving conditions now seem to have been exhausted. Growth in demand has resulted in a system that is now largely in balance, governments with increasingly constrained funds have withdrawn their state-owned enterprises from the development market, and the banking of merchant investments faces higher hurdles than ever before, having been intensified by the financial and economic crisis of FY09.

The broader industry has evolved in a manner in which these conditions can be navigated, if not imperfectly. With the introduction of capacity payments or other additional reliability mechanisms having been ruled out on numerous occasions by policy makers, industry participants reorganised themselves into Vertically Integrated (VI) merchant utilities spanning

\footnotetext{
* Paul Simshauser is the Chief Economist at AGL Energy Ltd and Professor of Finance at Griffith University's Business School. The author is grateful for the peer review of this article by Kirsty Norris, General Manager- Carbon and Sustainability (AGL Energy Ltd), Vijendra Satkunasingham (ANZ Bank), Dr Thao Doan (from power generator Stanwell Corporation Limited) and two anonymous referees.

${ }^{1}$ See for example IEA (2005) at p.14.
} 
generation and retail supply. ${ }^{2}$ Most importantly, all VI merchant utilities with a franchise retail base have investment-grade credit ratings and as this paper later reveals, such ratings are quite fundamental to navigating Resource Adequacy. And historically at least, the trajectory of regulated default retail prices have provided these firms with a stable and directionally appropriate revenue streams in which to retain their credit ratings, which is the key enabler to underwriting or directly investing in any requisite new plant.

Wholesale market prices have, however, been marked by rising volatility since 2007 and as this article later explains, importing the full-force of this volatility into regulated retail prices has the clear potential to disrupt the conditions required for future investment. At least two states in Australia, New South Wales (NSW) and Western Australia (WA), have managed to short-circuit this risk by moving to a regulated retail price comprising a Market-Based Wholesale Energy Cost allowance with a long run marginal cost (LRMC) 'floor'. And at the time of writing a third state, South Australia (SA), was also pursuing this strategy in their pre-determination working papers. While it is true that regulated prices are merely a 'price to beat', they nonetheless set the tone for industry profitability given the asymmetric nature of regulated retail prices on the one hand, and the imperfect nature of customer switching on the other. The combination of industrial organisation by firms whilst maintaining investment grade credit ratings, and regulatory strategy, would appear capable of reducing the most adverse risks of Resource Adequacy that otherwise exist in energy-only markets. Thus, the purpose of this paper is to review the history and outlook of Resource Adequacy in the NEM.

This paper is organised as follows; Section 2 reviews the power plant investment task facing the NEM. Section 3 introduces the Resource Adequacy problem that exists in energy-only markets and Section 4 examines the important concept of "bankability" as it relates to new plant investments. Sections 5 and 6 then explore how industrial organisation and the regulated price setting process have been the more recent mechanisms that help the market navigate the Resource Adequacy problem. Concluding remarks follow.

\section{The power plant investment task in the NEM: 2009-2020}

Demand for electricity in the NEM has been characterised by comparatively strong growth by OECD standards, increasing at 2.8\% pa over the 10 years to 2009 (ESAA, 2009). Forecasts to 2020 by AEMO (2009) indicate that peak load will increase from the current 36,000MW to about 43,000MW. Historically, any analysis of industry stability could focus exclusively on conventional energy sources, because the market shares in Australia could be summarised simply as $82 \%$ coal, $12 \%$ gas, $6 \%$ conventional utility-scale hydro with other renewable technologies representing little more than a rounding error. This is no longer the case. In 2009, legislation was passed by the Federal Government which enforces an expanded 20\% Renewable Energy Target (RET). This legislation builds on the earlier 2\% Mandated Renewable Energy Target (MRET). The most practical way in which to examine the regulated demand for renewable energy is in Figure 1, which sets out Australia's baseline renewable generation (i.e. pre-1997 renewable generation output), to which the $2 \%$ MRET was added in 2002, followed by the $20 \%$ RET in 2009.

\footnotetext{
${ }^{2}$ The transmission and distribution network monopolies are structurally separated and regulated.
} 
Figure 1: $\quad$ Renewable energy production and targets in Australia

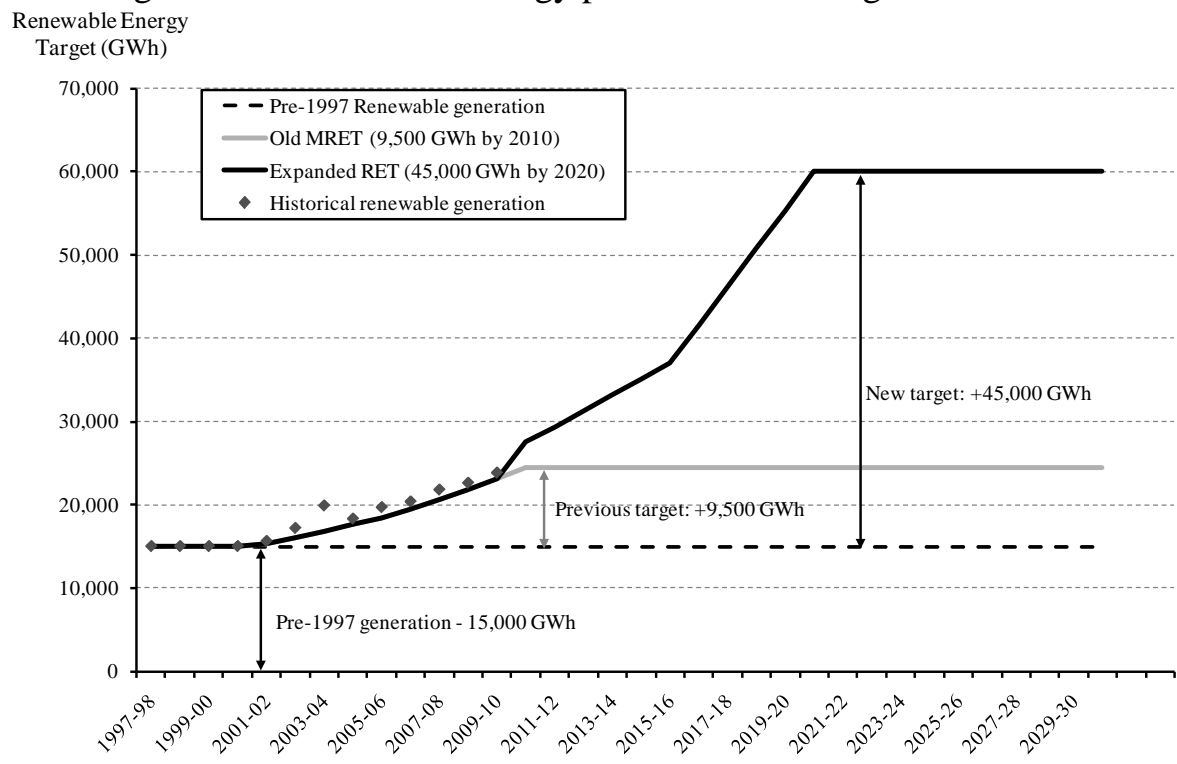

Source: Roam, AGL Energy Ltd.

The pre-1997 renewable energy 'baseline' production level primarily represents output from conventional utility-scale hydro schemes such as the Snowy Mountains, Victorian Alps, North Queensland and Tasmanian hydroelectric schemes. The MRET required an additional 9500GWh of production from new (post-1997) renewable sources, or 'above-baseline' improvements from the existing (i.e. pre-1997) fleet. Actual renewable generation between FY98 and FY09 is also marked in Figure 1 (i.e. diamond-shaped labels) and illustrates that in all years, the regulated incremental demand target was met.

The RET requires an additional 45,000GWh. The tenor of this target was originally planned to decline from 2025, but was extended out to 2030 just prior to being introduced into parliament. The aim of this was to ensure that regulated market demand would have sufficient tenor to assist the 'banking' of projects. This final-minute adjustment to the RET legislation was a subtle but critical indication that scheme designers were sensitive to the fundamental requirements of investors, the importance of which will become clearer later in this article. The implications for future investment patterns in the NEM between 2009 and 2020 are illustrated in Figure 2. Two investment scenarios are presented; the first examining the plant stock with the original $2 \%$ MRET target and the second incorporating the 20\% RET. As noted in Simshauser (2010), the investment task has increased from $\$ 17$ billion to $\$ 32$ billion, with renewable generation increasing from about 1200MW to about 9500MW of additional capacity. 
Figure 2: $\quad$ Forecast of new generation plant from 2009 to 2020 in the NEM

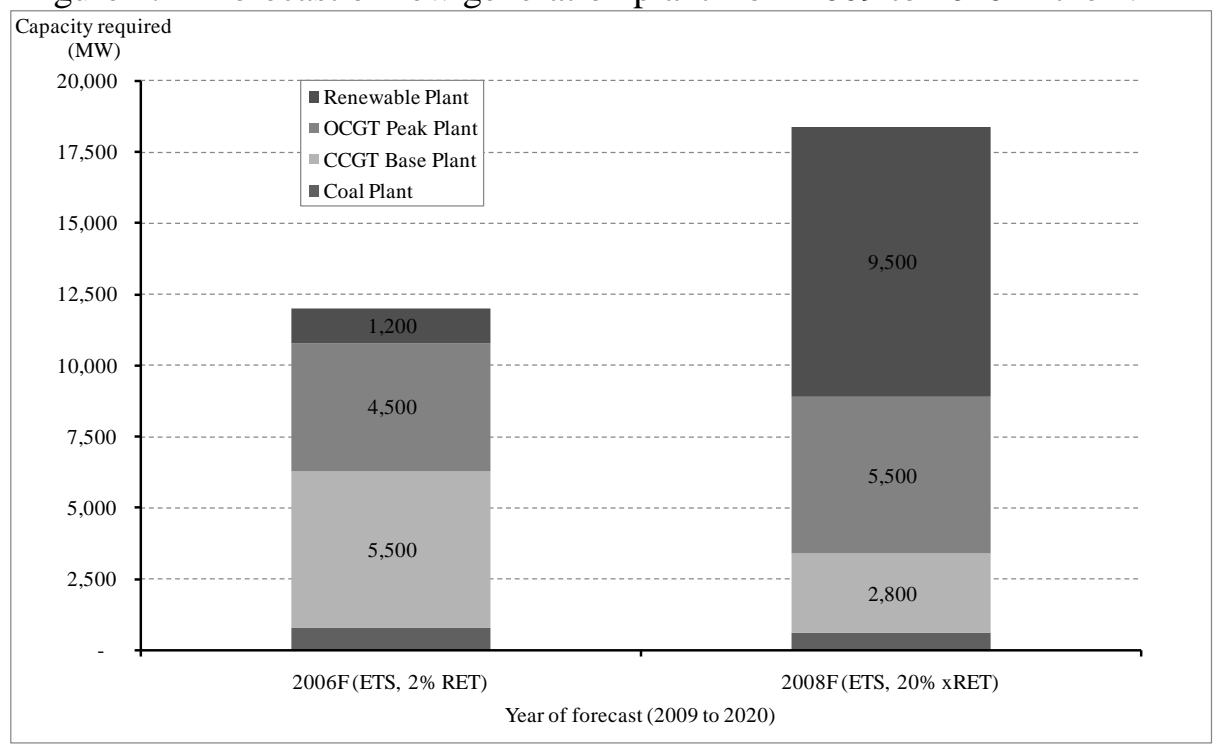

Source: AGL Energy Ltd, Simshauser (2010).

\section{On Resource Adequacy in energy-only markets}

The concept of Resource Adequacy, that is, the potential for insufficient generating plant capacity relative to aggregate power system demand, is well understood in energy economics (de Vries, 2002; Besser et al. 2002; Oren, 2003; Peluchon, 2003; Bidwell et al. 2004; Neuhoff et al. 2004; de Vries et al. 2004; Wen et al. 2004; Bushnell, 2005; Roques et al. 2005; Cramton and Stoft, 2006; Joskow, 2006; Simshauser, 2008; Finon, 2008 amongst others). The primary issue here is not that plant won't eventually be built, but whether or not it will arrive on a timely basis to maintain reliability of supply, and the common thematic in the academic literature is that prices in energy-only markets are inherently unstable at the wholesale level because generators are only paid for what they produce (i.e. there are no capacity payments to cover the heavy fixed costs of the power station fleet). Prima facie, this may appear to be no different to other commodity markets such as aluminium, where no fixed payments exist. But electricity markets differ from other capital-intensive commodity markets such as aluminium in that electricity is not a globally traded commodity; markets are tightly geographically concentrated and by implication, there is often a congestion of technologies and unit fuel costs across the power station fleet. In addition, electricity cannot be cost effectively stored, thus production must occur as demanded. In consequence, short-run marginal costs tend to be 'compressed' and as a result, energy-only markets are most unlikely to be remunerative under stable operating conditions.

In an attempt to counter-balance these characteristics, energy-only markets often incorporate very high wholesale market price caps, set at several hundred times average spot prices. In the NEM for example, the market price cap for spot electricity and for Frequency Control Ancillary Services (FCAS) ${ }^{3}$ is currently set at $\$ 12,500 /$ MWh against system average spot prices of about \$40-\$50/MWh. As IES (2009, pp.1-2) noted:

It is generally agreed that for an energy only market, such as the NEM, to be sustainable, it must provide for generators to recover their fixed (capacity) and variable (fuel) costs. Necessarily therefore, although for much of the time spot prices might reflect variable

\footnotetext{
${ }^{3}$ Operating reserves or FCAS in the NEM are split into Regulation (instantaneous raise and lower services via Automatic Generation Control) and Contingency (raise and lower 6 second, 60 second and 5 minute services). Payments for FCAS services comprise about $73 \%$ of all ancillary service payments in the NEM but represent little more than $1-2 \%$ of total energy market value. For further details, see http://www.aemo.com.au/electricityops/0160-0025.pdf.
} 
costs only, at other times, spot prices must be very high so that average spot prices, calculated over any extended time period, provide generators payments that match their total costs.

Generators are known to be prone to what Cramton and Stoft (2006) described as 'missing money'. The basic tenet of the 'missing money' concept is that equilibria in energy-only markets do not cover the average cost of the power station fleet given the presence of heavy fixed costs under conditions of intense competition, a reliability constraint and importantly, artificially low market price caps. The concept of missing money does of course require a time measurement. As one reviewer noted, if the historical economics of a given plant are measured over $n$ years, the investment may appear unprofitable. But if measured over $n+1$ years and the additional year incorporates, for example, drought conditions as occurred in the NEM in 2007, then the economics may in fact look highly favourable. A key issue here is that the financing arrangements of plant invariably involve quarterly debt obligations. This is an example of where economic theory and the harsh reality of real-world corporate finance quite simply collide.

While on paper a power project may appear NPV positive, if a plant misses debt covenants over (usually) three or four consecutive quarters, it will find itself in lockup at best, or in outright default and financial distress at worst. To this end, Bidwell and Henney (2004) observed that competitive energy-only markets are only remunerative if the power grid is virtually on the edge of collapse, which is of course politically unpalatable.

The presence of reliability constraints, which in the NEM is defined as no more than 1GWh of lost load for every 50,000GWh served (or $0.002 \%$ ) means that even with a market price cap of $\$ 12,500 / \mathrm{MWh}$, reliability objectives will constrain remunerative pricing under competitive conditions. Indeed, modelling results in Simshauser (2008) revealed that given current policy settings, only 57-65\% of costs would be recovered throughout the various NEM sub-regions. To achieve $100 \%$ cost recovery in the NEM, the market price cap would need to be lifted to about $\$ 24,500 /$ MWh given the NEM's stated reliability criteria. But this of itself raises subsequent problems such as systemic risks, that is, the risk of financial collapse by a participant if exposed to such extraordinarily high spot prices for any meaningful period of time.

There are of course other alternatives to achieve remunerative pricing. Fixed capacity payments are one such solution in that they effectively 'capitalise' and convert notional price spikes into a continuous income stream. Another similar solution is creating reliability markets in which the system operator calls for financial contracts based on set reliability criteria. ${ }^{4}$ However, capacity payments have been canvassed and rejected on numerous occasions by NEM policy makers.

Hogan's (2005) operating reserve demand curve concept has the potential to make a demonstrable difference to energy-only outcomes, although the evidence from the NEM's cooptimised energy and FCAS markets, despite a market price cap of $\$ 12,500$, remains highly unpredictable and therefore cannot be relied upon as remunerative.

Demand Response is the other obvious candidate for dealing with Resource Adequacy. However, as Vazquez, Rivier and Perez-Arriaga (2002) noted, in most cases consumers are isolated from spot prices by average tarification. Indeed, the evidence is that Australian consumers are demonstrably moving in the wrong direction in this regard. Far from becoming more interactive with the market, the number of households in Queensland's (QLD) capital, Brisbane, increased by $35 \%$ over the 12 years to FY10, whereas peak electricity demand by those households increased by $104 \%$ over the same period; air-conditioner penetration had risen from $23 \%$ to $72 \%$ with $34 \%$ of homes running two or more air-conditioners (Orchison, 2010). Until smart meters

\footnotetext{
${ }^{4}$ See for example Vazquez, Rivier and Perez-Arriaga (2002).
} 
and dynamic (and therefore deregulated) retail pricing prevails, it is hard to envisage meaningful Demand Response in the context of Resource Adequacy in the NEM.

It follows that consumers in the NEM face the risk that power prices will remain substantially below entry costs in the period leading up to a capacity shortfall. Given the very material construction lags associated with power plant development, being between 18 months and 40 months depending on the technology selected, the possibility that power project proponents will mis-time their investments, leading to transient price shocks and load shedding events during the period spanning any investment lag, is far more than a theoretical possibility.

The literature on Resource Adequacy can be loosely traced back to von der Fehr and Harbord (1995). They noted that the combination of construction lags, lumpy plant entry, the sheer term of the investment and regulatory uncertainty make merchant generation investments unusually risky. But the first contributions that described the difficulty of investment in peaking plant in energy-only markets was Doorman (2000), De Vries (2002) and Stoft (2002). As these early observations began to crystallise with reserve margins on the decline, Resource Adequacy became a mainstream issue. From then, Peluchon (2003), Roques et al. (2005), Joskow (2006), Simshauser (2008) and Finon (2008) amongst many others observed its presence; first in Europe, then England \& Wales, and then in the US and Australia. There is a reason for this progression.

Deregulated energy-only markets around the world initially thrived on their inheritance of capacity oversupply built up by the public monopolies that previously existed. Australia's NEM was no exception. Table 1 sets out the NEM's opening plant stock in 1998 and compares this to 'system optimal conditions'. Optimal results have been produced by a model called NEMESYS, which is a dynamic, partial equilibrium model of the NEM power system with half-hourly resolution and price formation based on a uniform, first price auction consistent with the NEM design. ${ }^{5}$

Table 1: $\quad$ Optimal plant mix at NEM commencement in 1998

\begin{tabular}{|l|r|r|r|l|}
\hline Operating Duty & Optimal & Actual & Imbalance & Weighting \\
\hline (Peak load: 24,970MW) & $(\mathrm{MW})$ & $(\mathrm{MW})$ & $(\mathrm{MW})$ & \\
\hline Base Load Plant & 20,400 & 24,500 & 4,100 & Overweight \\
\hline Intermediate Plant & 1,900 & 2,100 & 200 & Overweight \\
\hline Peak Load Plant & 5,800 & 6,600 & 800 & Overweight \\
\hline Aggregate Supply & 28,100 & 33,200 & 5,100 & Oversupplied \\
\cline { 2 - 4 } & & & & \\
\hline Capital Stock (\$M) & $\$ 26,736.00$ & $\$ 31,792.00$ & $\$ 5,056.00$ & Overcapitalised \\
\hline
\end{tabular}

Aggregate 'actual' supply in Table 1 is 33,200MW, some 5100MW above system requirements, and represents a 33\% reserve plant margin (vs. the world benchmark of c.15\%). Base load plant was materially 'overweight' at $+4100 \mathrm{MW}$. Using $2009 \$$ replacement cost estimates, the actual plant stock represents an investment of $\$ 26.7$ billion which is $\$ 5.1$ billion (19\%) above optimality. With this level of oversupply, it is clear that Resource Adequacy and the adverse consequences on investment arising from the missing money concept were highly unlikely to emerge as key policy issues in the first seven years of the NEM's operation. On the contrary, most investment activities by government owned generators in the NEM had, at least until the mid-2000s, been pre-emptive by any financial or physical measure, thus negating the adverse investment consequences of the missing money concept. In fact, a common and generally accepted criticism of government owned power developments was the 'front-running' of asset deployment.

${ }^{5}$ The model specifications which produced the results in Table 1 have been detailed in Simshauser (2008) and accordingly will not be reproduced here. 
There is no better contrast of the extent of early asset development than that of Queensland (dominant public ownership) and Victoria (exclusively private ownership) through the late-1990s and early-2000s. Figure 3 illustrates the aggregate impact of investment timing in the two respective NEM sub-regions by comparing actual reserve plant margins. Optimal reserve margins have been plotted for QLD and Victoria (VIC), and form the benchmarks for which to compare Resource Adequacy against. Given that VIC was interconnected to both NSW and SA, required reserve was $15 \%$. QLD's optimal reserve was $25 \%$ when it was operating as an isolated grid, and $18 \%$ following interconnection with the NEM via NSW in $2001 .^{6}$

As the NEM was formed in 1998, reserve margins prior to this point in Figure 3 were driven by centrally planned investment decisions made earlier. Thereafter, reserve margins were the outcome of deregulated investments. Note in VIC that reserve margins reduced to slightly below optimality during 2001 and again in 2004 which in turn led to system stress during the summer months. The market responded with new investment, albeit delayed by approximately 12 months on both occasions. This is of course consistent with Cramton and Stoft's (2006) missing money concept; at each event in VIC, investments were eventually banked by the private sector to restore system balance, but exclusively through direct investment or underwriting via long-dated Power Purchase Agreements (PPA) initiated by VI merchant entities.

Figure 3: $\quad$ Reserve plant margins in QLD and VIC (FY95 - FY05)

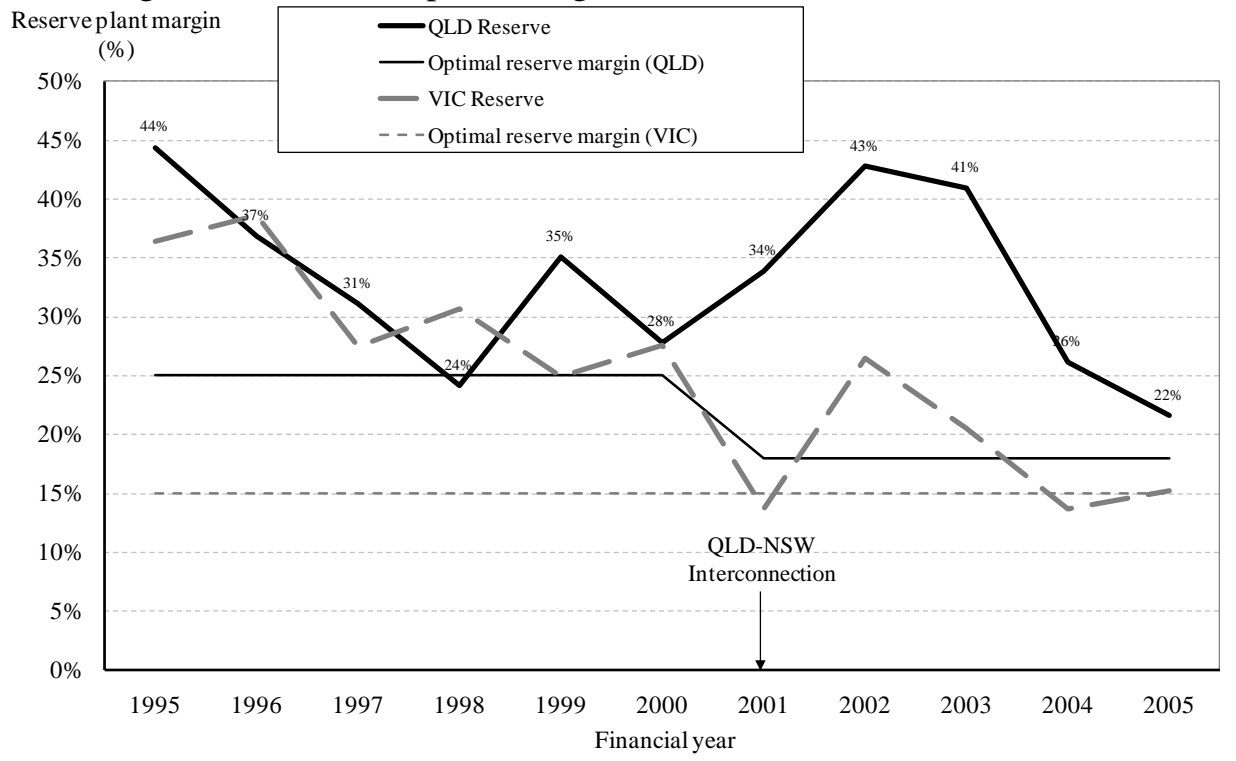

Source: Simshauser (2005)

It could be argued that the VIC investments were too late by one year on both occasions, but these outcomes could also be argued to have been less dysfunctional than the QLD result from a resource allocation perspective (particularly given that the reliability criteria was, in the end, met in VIC in 2001 and 2004 despite the marginal capacity shortfalls). In QLD, an overwhelming level of investment was made primarily by government owned generators at Callide in 2001, Tarong North in 2002 and Swanbank in 2002 (see Appendix I). A single private investment by InterGen was made at Millmerran in 2002, although much to the frustration of the investors because commitments to construct Tarong North and Swanbank occurred after Millmerran was committed in 1999. Unsurprisingly, both plants were widely regarded as un-commercial

\footnotetext{
${ }^{6}$ As QLD forms the 'northern end' of the NEM grid with interconnection limited to one other region (i.e. NSW), its required reserve to ensure system security will always be marginally higher.
} 
decisions at the time. ${ }^{7}$ Private investors at the proposed 750MW Kogan plant in QLD were crowded-out completely, and so sold their holdings to a government owned generator, who in turn developed the asset a few years later. The special case of the Kogan plant will be dealt with more fully in a later section.

The importance of this is clear. The propensity of the deregulated power grid to deliver Resource Adequacy under a primarily government-owned system was unquestionable. Balance sheet financings enabled 'value investments' ${ }^{\text {' }}$ to be made, even if it involved early-year losses. However, the basis and timing of those investments was in almost all cases ahead of requirements and were therefore inconsistent with the principles of investment under uncertainty contained in the seminal academic works of Dixit and Pindyck (1994). Needless to say, spot energy prices in QLD from FY04 to FY06 traded at \$28/MWh, substantially below the then LRMC of \$35-\$40/MWh.

This history is well understood by the industry, policy makers and the regulatory authorities. More recently, state governments in QLD and in NSW have withdrawn from the development market to avoid the risk of crowding-out the private sector. This was a key finding of the "Owen Inquiry” into the NSW power industry (Owen, 2007). The general conclusion from the inquiry was that if state-owned businesses continued to invest, private sector participants may not enter the investment market for fear of subsequent losses incurred by uncommercial and ill-timed (preemptive) investments made by state-owned businesses, per the Millmerran experience in QLD, and in the event, state governments would find themselves in a vicious circle of forcing their own balance sheets to continue to respond to investment requirements into the future.

The aggregate plant stock in Australia at the start of the 1990s was owned entirely by stateowned electricity commissions, and all power stations were developed 'on balance sheet' (Simshauser, 2009). But private sector participation on the supply-side is on the rise. By FY08, private sector participation in power assets had increased to 39\%, and by the end of FY11 following the expected NSW privatization process, that number will increase to about $60 \%$. Government businesses have withdrawn or have been constrained from entering the development market, with the final two power projects built and financed by the public sector (using onbalance sheet funding) being the 750MW coal plant at Kogan in Qld, and the 660MW open cycle gas turbine at Colongra in NSW in 2007 and 2009 respectively.

Thus between the initial endowment of monopoly-built plant inherited by the market in 1998, and the pre-emptive investments made by government-owned generators, Resource Adequacy has until recently barely rated a mention in the NEM. Roques et al. (2005), Joskow (2006), de Vries and Heijnen (2007) and Finon (2008) identified why this is the case. Apart from the fact that there has been insufficient experience with deregulated energy-only markets to conclude that investment will be timely and adequate, more critically, they noted that the world's electricity markets are only just beginning to approach their first major 'investment cycle' as surplus capacity from the pre-reform era and initial pre-emptive post-deregulation investments are finally being absorbed. Australia's NEM certainly fits with this description as indicated by Table 2 . Note that the system reserves had reduced from 33\% in (Table 1) to just 18\%, and that peak plant was officially 'underweight' by FY09.

\footnotetext{
${ }^{7}$ It is worth noting that the investments at those sites would have most certainly been economic at a later date. The issue was that they were developed pre-emptively as evidenced by the time-series data in Figure 3.

${ }^{8} \mathrm{~A}$ 'value investment' is where the present value of future cash flows is positive, but early-year losses imply delaying by one year or more would increase investment returns. In contrast, a 'yield investment' has positive early-year returns to equity and present value of future cash flows, as one would expect.
} 
Table 2: $\quad$ Optimal plant mix for the NEM in FY09

\begin{tabular}{|l|r|r|r|l|}
\hline Operating Duty & Optimal & Actual & $\begin{array}{r}\text { Imbalance } \\
\text { (Peak load: 35,700MW) }\end{array}$ & Weighting \\
\hline Base Load Plant & 25,000 & 26,700 & 1,700 & Overweight \\
\hline Intermediate Plant & 3,600 & 5,900 & 2,300 & Overweight \\
\hline Peak Load Plant & 11,600 & 9,900 & -1700 & Underweight \\
\hline Renewables & 1,700 & 1,700 & 0 & Balanced \\
\hline Embedded Generation & 1,000 & 1,000 & 0 & Balanced \\
\hline Aggregate Supply & 42,900 & 43,500 & 2,400 & Oversupplied \\
\hline & & & & \\
\hline Capital Stock $(\$ M)$ & $\$ 48,521.30$ & $\$ 51,963.10$ & $\$ 3,441.90$ & Overcapitalised \\
\hline
\end{tabular}

By comparison to the results in Table 1, this represents a much more balanced market, with the system now overcapitalised by just $6.6 \%$ compared to $19 \%$ in 1998 . Consistent with the thematic contained in Roques et al. (2005), Joskow (2006), de Vries and Heijnen (2007) and Finon (2008), the NEM is now facing its first major investment cycle, the magnitude of which was aptly captured in Figure 2 at \$32 billion over the next 10 years. The State of QLD will retain ownership of some generating plant, but has shown no interest in further participation beyond its existing asset allocation. The other state governments have withdrawn completely, with NSW set to allocate its interest in existing generation stock to the private sector through a series of contractual arrangements later in FY11. Accordingly, 100\% of new power projects will require private sector funding. With this in mind, the 'bankability' of power projects will, for the first time in the NEM's history, take on a critical importance.

\section{Understanding the limitations of power plant investments: "bankability"}

The concept of missing money, as it applies to Australia's NEM, has intensified over time despite increases in the market price cap and the introduction of eight separate FCAS markets. ${ }^{9}$ As explained in Simshauser, Molyneux and Shepherd (2010), power systems have experienced an 'entry cost shock' over the period spanning 2004-2009. In the case of NSW for example, system average costs increased from about $\$ 45 / \mathrm{MWh}$ to $\$ 60 / \mathrm{MWh}$. This cost shock was found to primarily affect fixed costs; the $\$ 15 / \mathrm{MWh}$ increase being split between rising plant capital costs (70\%), rising costs of capital (25\%) with operating costs representing the balance. This increase has widened the 'average-to-marginal cost gap' and is illustrated in Figure 4.

\footnotetext{
${ }^{9}$ The eight co-optimised markets include regulation services (raise and lower), 6 second, 60 second and 5 minute raise and lower contingency services.
} 
Figure 4: Average cost and short-run marginal cost of base load coal plant

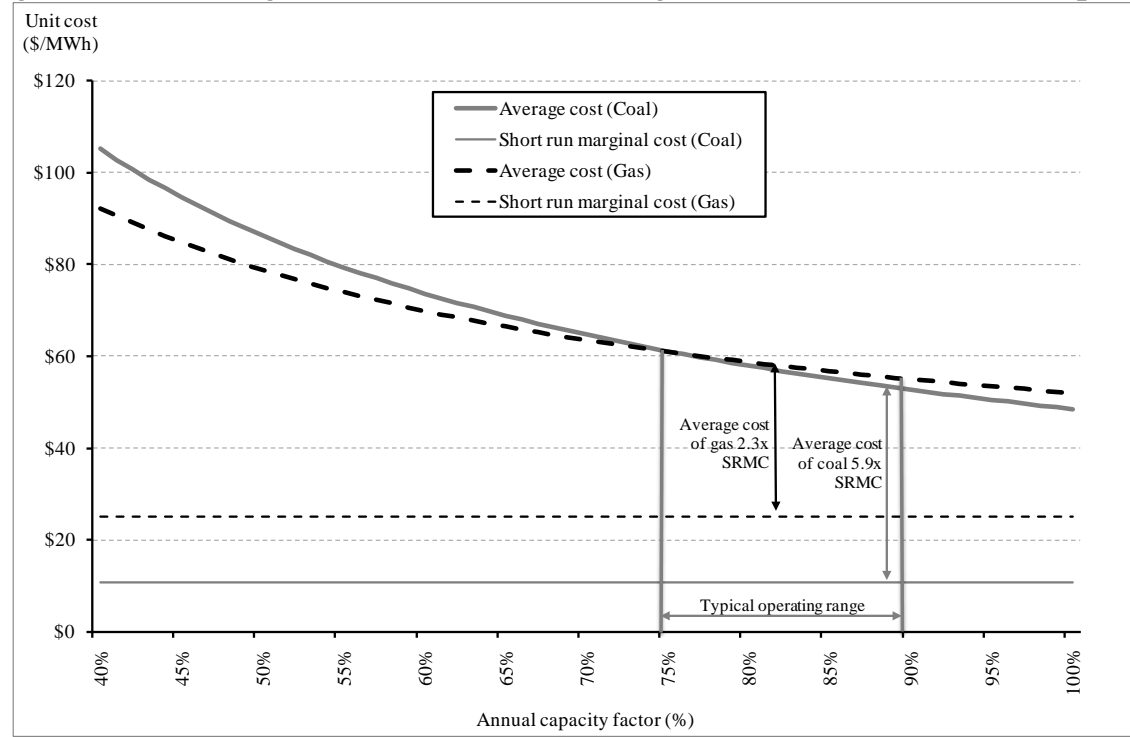

In Figure 4, the average cost function of new coal and new CCGT plant has been plotted along with their marginal running cost curves. Note that within the typical base load operating range of 75-90\%, average cost is 5.9 times the marginal running cost function for the coal plant. This compares to 2.9 times for the QLD coal fleet at the start of the NEM in 1998, and 3.3 times in $2004 .^{10}$ Gas plant has a lower gap at 2.3 times, having increased from 2.0 times in 2004, but of course faces the low marginal running costs of coal plant. The importance of this is that since base plant set price for many hours of the year, the cost recovery task is heightened whenever fixed costs rise relative to marginal running costs. And clearly in the NEM, this is occurring.

Counter-arguments to the missing money concept typically relate to (1) raising the market price cap and/or generators withholding capacity in order to raise spot prices, and (2) the ability of 'the market' to forecast shortfalls and invest on a timely basis because a forecast should account for the predicted undersupply and be reflected in any spot price forecast.

On the first matter, as noted earlier the market price cap in the NEM has been raised from the initial $\$ 5000$ to $\$ 10,000$ and more recently to $\$ 12,500$ and a current review is likely to reset this to $\$ 16,000$ in two years time. But modelling in Simshauser (2008) indicated that to balance costs the wholesale price cap needs to be set at about $\$ 24,500$ which in turn would raise systemic risk issues. There is evidence that the economic withholding of capacity has driven remunerative pricing in the NEM. ${ }^{11}$ But the political economy of electricity prices means that an inherent bias by regulators exists to 'lean on electricity prices' at the wholesale level. The Australian Energy Regulator (AER), for example, has a policy of systematically investigating all wholesale price spikes above $\$ 5,000 / \mathrm{MWh}$, and at the time of writing was prosecuting a generator for the economic withholding of capacity in a manner that was inconsistent with the NEM's Rules. The key policy issue here becomes one of distinguishing at what point strategic behaviour crosses a line and becomes at odds with market rules, i.e. an abuse of market power. There is no clear set of rules or regulatory enforcement agency that can effectively define this cross-over point for the industry at this stage. Given this regulatory uncertainty, it could be argued that market participants will err of the side of caution and limit strategic behaviour. Regardless, policy makers and regulators could hardly explain to electricity consumers that they are relying on strategic behaviour to negate the effects of the missing money concept to ensure timely

\footnotetext{
${ }^{10}$ See Simshauser (2006) at p.135 for details of the calculated average-to-marginal cost ratios in QLD in 1998 and 2004

${ }^{11}$ For example, see Simshauser (2001) at pp. 77-78 and French J (2003).
} 
investment; although as one reviewer noted, this reflects the manner in which most energy-only markets are left to function.

The second matter goes to the heart of understanding the limitations of investment decisions in the world's most capital-intensive industry, and the third largest user of debt capital behind governments and the banking sector respectively. The barriers to entry in power generation are very substantial because of the large upfront investment required to build plant, ranging from $\$ 350$ million to $\$ 2$ billion, and the highly specific technical skills required to run power stations and energy trading desks. This can be conveniently condensed into a single conceptual hurdle called the "bankability" of new plant. ${ }^{12}$

Given the capital intensive nature of generation investments, the majority of private power plants are project financed. For example, at the start of the NEM there were 20 privately owned plant, and since the NEM's formation, there has been an additional 29 thermal plant developments made by the private sector (see Appendix I). $82 \%$ of this plant capacity has been project financed, with the balance funded by the use of corporate debt facilities. Finon (2008) observed that this has been a global trend. Accordingly, a brief note on project finance is warranted at this point.

A project financing involves lending against a single asset with a long expected useful life (25+ years) with relatively predictable future cash flows. The tenor of debt finance is usually longdated money of up to 12-years within a semi-permanent structure, that is, a notional 25-year repayment profile. Most importantly, project financings are structured as limited-recourse loans to the asset owners where the security provided is the asset and its expected future cash flows. In turn, the banks will place a number of 'debt covenants' and 'contractual thresholds' upon term debt facilities to ensure their debt finance is protected. ${ }^{13}$ The most important covenants are the financial ratios; the debt service cover ratio and loan life cover ratio which ensure adequate cash buffers exist between the plant's cash flows available for servicing present and future debt obligations. Contractual thresholds relate to technology specifications and commercial arrangements. The technology selected needs to be mature and supplied by a reputable manufacturer (e.g. GE, Siemens, Alstom, Mitsubishi Heavy Industries etc). Modern bankability requirements typically involve fuel contracts with fixed prices and quantities, and most critically, revenues being primarily contracted by way of long-dated PPAs (or similar hedge contracts). Crucially, to be bankable, PPAs must be written by a counterparty with an investment grade credit rating (i.e. $\geq$ BBB-). For clarity, it is simply not sufficient for a generation developer to collate a portfolio of end-use customers. For this approach to be acceptable, tfhe legal structure that holds those customers would need to obtain a credit rating to demonstrate it is of sufficient credit quality to write a PPA capable of underwriting a power project financing.

The primary benefit of project finance is that power station investors can typically obtain between $60 \%$ and $80 \%$ of the investment requirement through syndicated project debt. ${ }^{14}$ This of course achieves two primary benefits; first, it lessens the risks and costs associated with large equity capital raisings; and second, it lowers the weighted average cost of capital given the higher cost of equity capital. ${ }^{15}$

\footnotetext{
${ }^{12}$ Bankability simply means an investment project that is in a state sufficient to be bankable and raise the requisite debt finance.

${ }^{13}$ Smith and Warner (1979) provide a comprehensive discussion on debt covenants.

${ }^{14}$ In 'syndicated' project financing, Mandated Lead Banks commit to a 'take and hold' amount and an 'underwritten' amount for subsequent syndication. Following the financial crisis, 'Club Deals' have become more common, where project banks participate on a 'take and hold' basis only, thus avoiding the risk associated with debt syndication (Simshauser, 2009).

${ }^{15}$ This point is contentious given that higher gearing magnifies the volatility, and therefore the risk profile of equity returns. Nonetheless, the real-world evidence tends to point to a 'maximise debt' gearing strategy by power station investors. For a more detailed discussion, see Simshauser (2009, p.11).
} 
The common presumption, and indeed misconception, by policy makers, regulators and nonprivate sector participants, is that once a median case spot price forecast exceeds entry costs, investments will rush to fill the looming gap in supply. In the power industry, this is where economic theory and the harsh realities of corporate finance collide. To be sure, it was once not an unreasonable presumption. Pre-2000 Greenfield investments in the NEM (e.g. the 840MW Millmerran coal plant banked in 1999) and pre-2000 privatised generators in VIC and SA were able to obtain project finance on a merchant basis or with 'vested contracts' of approximately five year terms, respectively. This was reflective of the initial enthusiasm for deregulated energy markets.

But the subsequent financial distress experienced by a large number of these facilities in the NEM in the years following provided a brief and bitter lesson to the banking syndicates that project financed merchant plant. And importantly, this was a global phenomenon. Joskow (2006) noted that in the US, about 230,000MW of new plant was added between 1997 and 2005; this massive wave of investment was mostly made by Independent Power Producers in merchant plants relying on project finance. However, as Finon (2008, p.153) noted:

Above all, most projects [in the US] were bankrupt after 2001... By 2004, 90,000MW was turned back to lenders, 23,000MW had been bought by private investors and 10,000MW had been repurchased by regulated utilities... Lenders have, since then, been much more cautious on how to finance new projects... Lenders and financial markets have changed their reference model of electricity markets [from merchant plant] and now favour vertical integration and long term contracts.

The experience in England \& Wales was no different. Finon (2008) noted that about 5800MW of new CCGT plant was developed as merchant plant but only two were effectively achieved after 2002. Since then, all new projects in England \& Wales have been 'developed by vertically integrated companies for supplying their retail market, with very few exceptions’ (Finon, 2008, p.154).

From the brief description of the power project investment magnitude, task, and 'bankability' requirements outlined above ${ }^{16}$, it should be abundantly clear that the mere existence of a 'rosy spot price forecast' is quite simply insufficient to enable a power development to obtain project finance and proceed to commitment. Indeed, as Finon (2008, pp.150-151) noted, 'the canonical business model in generation of the merchant plant, a stand-alone producer that sold its production on short-term markets without long-term contracts, and developed new capacity under project financing by non-recourse debt' is entirely inconsistent with real-world events.

As noted earlier, revenues need to be primarily contracted by way of long-dated PPAs to provide a degree of certainty to project bankers and need to be written by counterparties with an investment-grade credit rating. Analysis of revenue source for new entrant plant in the NEM from the data contained in Appendix I, summarised in Table 3, confirms this to be the case. Note that $6,309 \mathrm{MW}$ or $55 \%$ of all new generating capacity in the NEM has either been originated or underwritten by AAA-rated government businesses between 1997 and 2011F (and as an aside, a surprisingly large 73\% of all new plant between 1997 and 2007, see Appendix I). On the other hand, private sector merchant investments (i.e. reliant on spot and short-dated hedge contracts) represent just $9 \%$ of investments. Most importantly, not a single purely merchant investment has occurred in the NEM since Millmerran, which reached financial close in 1999. The remaining investments of 4050MW, all of which have occurred since 2002, have been originated or underwritten by VI merchant utilities with credit ratings of BBB- or better, all of which remain

\footnotetext{
${ }^{16}$ In particular, the requirement for revenue to be primarily contracted by way of PPAs or similar hedge contracts with reputable, investment grade counterparties with limited exposures to spot prices.
} 
'inherently short' energy. The critical importance of this becomes clearer later in this article, in Sections 5 and 6.

Table 3: $\quad$ Analysis of new entrant plant revenue source (2007-2011F)

\begin{tabular}{lrr}
\hline The source of revenue for new entrant plant for financing purposes & $\begin{array}{r}\text { Capacity } \\
\text { (MW) }\end{array}$ & Share \\
\hline Govt Owned Corporation PPA & 2,851 & $25 \%$ \\
Government Owned Corporation as Principle Investor & 3,458 & $30 \%$ \\
Sponsored by Private VI Entity ( $\geq$ BBB- credit rating) & 4,050 & $36 \%$ \\
Private Sector Merchant & 982 & $9 \%$ \\
\hline TOTAL & 11,341 & $100 \%$ \\
\hline
\end{tabular}

The results from Table 3 are not at all surprising given the 'missing money' concept, which is in large part driving the heightened 'bankability hurdle'. The complexity of the merchant investment task in the NEM has been obvious at every 'lack of reserve' event thus far. In Tables 4 and 5, and in Figures 5 and 6, data from the years 2003-2005 inclusive is presented to illustrate the exact nature of the problem. The analysis focuses on VIC and QLD because 70\% of all new plant capacity has been built in these two regions of the NEM.

Each year the market operator, NEMMCo ${ }^{17}$, produces a "Statement of Opportunities" (SOO) which is a comprehensive document outlining supply, demand and forecast imbalances for the NEM. The data in this document is generally accepted as providing the most credible outlook for energy demand and is therefore widely used as a key market modelling input for investment purposes by participants and the investment community. Table 4 presents a summary of the key 2003, 2004 and 2005 SOO results and identifies when supply was predicted to be insufficient relative to the prescribed 'minimum reserve levels' for each of the primary regions of the NEM (NEMMCo, 2003, 2004, 2005).

If it is accepted that the SOO provides the most credible forecast of future energy demand, and given that the incumbent plant stock is easily defined, in theory we would expect to see prices rising and a stream of power projects making their way into the market whenever a 'lack of reserve' appears. Energy-only markets, like most commodity markets, tend to be highly cyclical. ${ }^{18}$ Given that plant investments typically occur 'at-scale', the lumpy nature of entry means that spot and forward prices tend to fall in the post-entry environment (Simshauser, 2001). With this in mind, one might expect to see forward prices rising well above LRMC in the immediate pre-entry environment, thus ensuring that post-entry economics remain favourable given the critical importance of early year cash flows in any discounted cash flow analysis. ${ }^{19}$ Yet quantitative evidence from the NEM couldn't be more stark in its departure from this seemingly logical economic deduction, and to illustrate this point we turn to quantitative evidence from the market. The 750MW Kogan coal-fired project in QLD provides a useful case study.

\footnotetext{
${ }^{17}$ NEMMCo was recently reconstituted as AEMO, the Australian Energy Market Operator. See www.aemo.com.au.

${ }^{18}$ Although European markets seem to be less cyclical with incumbents managing Resource Adequacy courtesy of imperfectly competitive structures.

${ }^{19}$ The counter argument to this is that discounted cash flow analysis fails to account for real option values. However, as Simshauser and Wild (2009) noted, project finance banks do not account for real options associated with a power station when sizing the initial debt facility.
} 
Table 4: $\quad$ Identified 'Lack of Reserve' events from the NEMMCo SOO (2003-2005) ${ }^{20}$

\begin{tabular}{|c|c|c|c|c|c|c|}
\hline $2003 \mathrm{SOO}$ & 2004 & 2005 & 2006 & 2007 & 2008 & 2009 \\
\hline QLD & \multicolumn{6}{|c|}{ Lack of Reserve 05/06 } \\
\hline NSW & \multicolumn{6}{|c|}{ Lack of Reserve 05/06 } \\
\hline VIC & \multicolumn{6}{|c|}{ Lack of Reserve 04/05 } \\
\hline SA & \multicolumn{6}{|c|}{ Lack of Reserve 03/04 } \\
\hline
\end{tabular}

\begin{tabular}{|c|c|c|c|c|c|c|}
\hline $2004 \mathrm{SOO}$ & 2004 & 2005 & 2006 & 2007 & 2008 & 2009 \\
\hline QLD & \multicolumn{6}{|c|}{ Reserve increased from 450 to $610 \mathrm{MW},+750 \mathrm{MW}$ Kogan committed } \\
\hline NSW & \multicolumn{5}{|c|}{ Reserve decreased from +700 to $-290 \mathrm{MW}$} & LoR 08/09 \\
\hline $\begin{array}{l}\text { VIC } \\
\text { SA }\end{array}$ & \multicolumn{3}{|c|}{ Joint reserve decr. from 795 to $530 \mathrm{MW}$} & $\begin{array}{l}\text { Lack of Res } \\
\text { Lack of Res }\end{array}$ & & \\
\hline
\end{tabular}

\begin{tabular}{|lrrrrr|}
\hline 2005 SOO & 2004 & 2005 & 2006 & 2007 & 2008 \\
QLD & +450 & Breamar OCGT plant committed & & 2009 \\
NSW & & & & LoR 08/09 \\
VIC & & & & LoR 08/09 \\
SA & & & & Lack of Reserve 07/08 \\
Lack of Reserve 07/08
\end{tabular}

Committed in response to the shortfalls identified in the 2003 SOO (per Table 4), the economics of the 750MW Kogan project in QLD were highly favourable for two reasons; first, fuel resources at site are low cost (sub $\$ 0.75 / \mathrm{GJ}$ ), and second, the timing of the project was just prior to the global run-up in plant capital costs and the cost of capital. ${ }^{21}$ Consequently, this low cost coal project had as good a chance as any to enter profitably in the NEM. The fully constructed project LRMC, assuming it had been project financed and built by the private sector, has been calculated at sub-\$35/MWh (2004 dollars) using the Project Finance model in Simshauser (2009). The project was committed in 2004 following the release of the 2003 SOO in Q3 2003, with production duties commencing on a full-year basis in 2008. ${ }^{22}$ By 2008 its LRMC was determined to be $\$ 37.75 / \mathrm{MWh}$ given four years of inflation from 2004 .

Figure 5 presents the pre- and post-entry environment facing Kogan, spanning the 36 months around irreversible project commitment. Note that at the point of project commitment in 1H2004, the long end of the electricity forward curve (i.e. the Cal 08 swap price) was trading at just over $\$ 37 / \mathrm{MWh}$ and trending towards the 2008\$ entry cost of Kogan at \$37.75. Predictably, project commitment had a marked and immediate downward impact on 2008 forward commodity prices, eventually falling below $\$ 33 / \mathrm{MWh}$ as Figure 5 notes. Future-dated base load derivative instruments for 2009 and 2010 also followed suit. Meanwhile, the real-time spot price trace, represented by the 12-month moving average of real time prices, remained substantially below entry costs throughout the 2004-2006 period as observed in Figure 5.

\footnotetext{
${ }^{20}$ Note that prior to the release of the 2004 SOO, NEMMCo modified the manner in which reserve margins were calculated, taking into account loads diversity and interconnector flows across NEM regions. This explains the marked lengthening in the expected shortfalls between the 2003 SOO result and the 2004 SOO result.

${ }^{21}$ The capital cost of Kogan was $\$ 1500 / \mathrm{kW}$ and the cost of capital on a nominal pre-tax basis would be around $10.7 \%$. This compares to the 2009F result in Simshauser, Molyneux and Shepherd (2010) of $\$ 2200 / \mathrm{kW}$ and $12 \%$ respectively.

${ }^{22}$ See http://www.csenergy.com.au/userfiles/KCPS\%20fact\%20sheet.pdf for details of the Kogan Power Project.
} 
Figure 5: Post-entry environment facing Kogan Creek Power Station

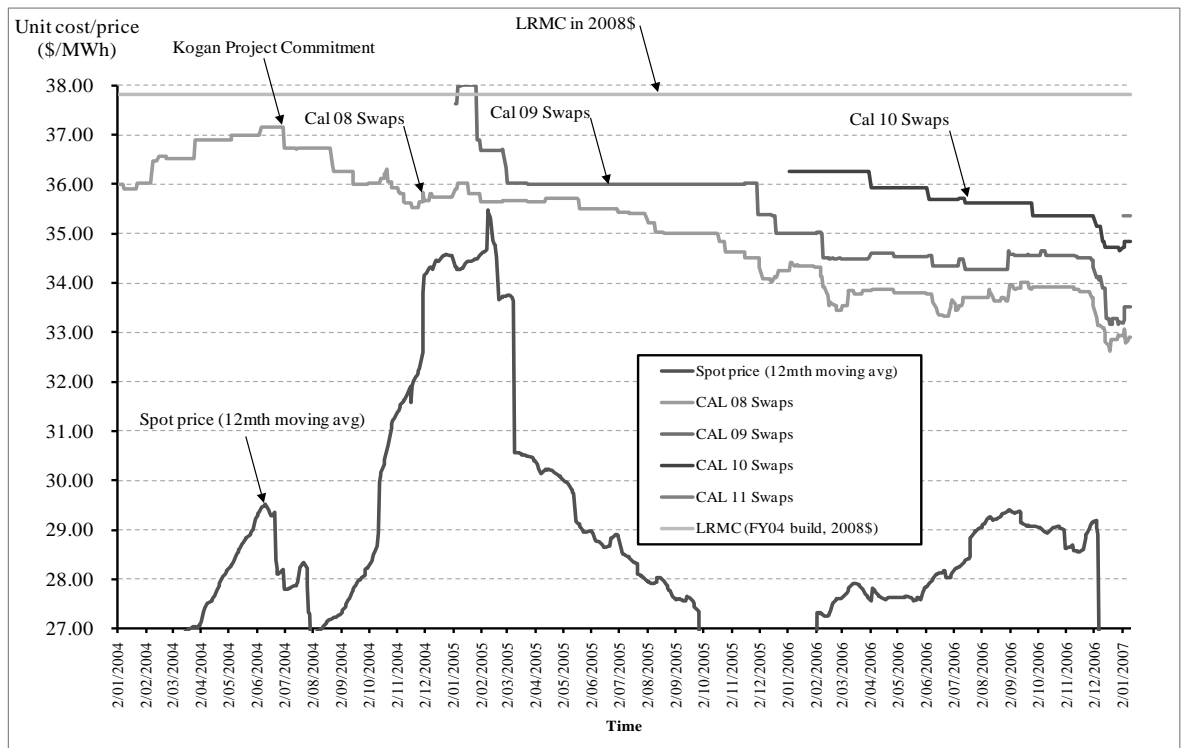

Source: ICAP, AEMO, AGL Energy Ltd.

To put the extent of this price collapse into context, expected annual equity returns from the \$1.1 billion project should be in the order of $\$ 73.1$ million pa from 2008 onwards in order for equity participants to achieve a fair return on their investment. But the expected shortfall to equity implied by the falling forward curve and associated spot price ${ }^{23}$ would have been $\$ 34.1$ million pa, thus reducing equity returns and the imputed running cash yield to equity from $13 \%$ to $6.5 \%$ or 16 basis points (bps) above the yield on 10-year government bonds. ${ }^{24}$ With APRA (2007) noting that Australian Superannuation (i.e. Pension) Fund Managers were returning 11.2\%, $11.5 \%$ and 12.4\% during calendar years 2004, 2005 and 2006, a forecast return of 16bps over long bond rates is hardly an inspiring risk-adjusted investment proposition for institutional equity investors.

Spot and forward prices ultimately increased substantially above entry costs during FY08 due to the impact of drought conditions on energy supplies, but this is beside the point. The key issue here is that at the point of commitment and in the years that followed, entry was uneconomic and expected returns were entirely suboptimal. That drought conditions ultimately drove prices above entry costs can be considered entirely serendipitous at best.

As noted earlier in Tables 1 and 2, the NEM has been consistently 'overweight' base plant and accordingly, reserve shortfalls identified in NEMMCo SOO's inevitably reflected inadequate peaking plant capacity, and so it could be argued that the analysis of the base load Kogan coalfired project is just another example of pre-emptive investment by a government-owned business. But the market signals for peaking plant were similarly inadequate.

In Table 5, the historic view of the LRMC of an OCGT peaking plant in the NEM is presented, expressed as the fixed carrying cost of capacity (i.e. fuel and variable maintenance costs are assumed to be recovered from spot market receipts when running). The source time-series data (i.e. plant cost and cost of capital) have been drawn from Simshauser, Molyneux and Shepherd (2010) with the LRMC (\$/MWh) results produced by the 'levelised entry cost model' documented in Simshauser and Wild (2009). Entry costs for each year are in-line with changes in

${ }^{23}$ \$28/MWh has been assumed which is consistent with the annual average spot price in QLD for FY04, FY05 and FY06.

${ }^{24}$ At the start of 2008, 10-year bonds were 6.34\% (Source: Reuters). 
the market for new plant and capital markets, and are projected forward $(\mathrm{t}+\mathrm{n})$ at $3 / 4$ of the assumed consumer price index, which is a common industry assumption.

Table 5: $\quad$ LRMC of OCGT peak plant

\begin{tabular}{|r|r|r|r|r|r|r|}
\hline Year & $\begin{array}{r}\text { Plant Cost } \\
(\$ / \mathrm{kW})\end{array}$ & $\begin{array}{r}\text { Cost of Capital } \\
(\%)\end{array}$ & $\begin{array}{r}\text { LRMC } \\
(\$ / \mathrm{MWh})\end{array}$ & $\begin{array}{r}\text { LRMC } \\
(\mathrm{t}+1)\end{array}$ & $\begin{array}{r}\text { LRMC } \\
(\mathrm{t}+2)\end{array}$ & $\begin{array}{r}\text { LRMC } \\
(\mathrm{t}+3)\end{array}$ \\
\hline 2003 & 757 & 10.8 & 9.95 & 10.14 & 10.33 & 10.52 \\
\hline 2004 & 723 & 10.7 & 9.50 & 9.68 & 9.86 & 10.04 \\
\hline 2005 & 789 & 10.6 & 10.15 & 10.34 & 10.53 & 10.73 \\
\hline 2006 & 828 & 10.6 & 10.57 & 10.77 & 10.97 & 11.18 \\
\hline 2007 & 1106 & 10.8 & 13.78 & 14.04 & 14.30 & 14.57 \\
\hline 2008 & 1122 & 11.7 & 14.94 & 15.22 & 15.51 & 15.80 \\
\hline 2009 & 985 & 12.0 & 13.61 & 13.87 & 14.13 & 14.39 \\
\hline
\end{tabular}

Source: Simshauser, Molyneux and Shepherd (2010)

The manner in which an OCGT peaking plant is 'banked' from a revenue perspective is through forward selling \$300/MWh call option or 'Cap' contracts. Forecast capacity factors for OCGT plant tend to be limited to between 5-30\% per annum in response to high price events associated with hot weather, cold weather and plant outages. By their very nature, such events may or may not eventuate in each quarterly period when financing costs become due and payable under a project financing. With a manifestly random production profile, and therefore a similarly random revenue stream from the energy only-market, premiums received from selling Cap instruments provide a critical continuous revenue stream to cover the fixed and financing costs associated with carrying peaking plant capacity throughout any given period.

To illustrate the disconnect between the energy-only market and the forward price of electricity, the subsequent analysis focuses on the 2005 SOO 'lack of reserve' events due to data limitations on Cap contracts prior to 2005. As Table 5 notes, plant costs in 2005 were $\$ 789 / \mathrm{kW}$ and the cost of capital was $10.6 \%$ (which as an aside represents the low point in plant costs in the current cycle). Yet despite this, when reserve shortages appeared across the NEM, (e.g. FY08 in VIC, Cal08 in QLD), Cap prices remained heavily discounted relative to entry costs as revealed in Figure 6. Note in particular the larger disconnect in VIC, in which Cap contracts traded at an average price of $\$ 6.16 / \mathrm{MWh}$ despite 'lack of reserve' warnings. At this price, returns to equity would be less than $1 \%$ or 540 bps below prevailing 10 -year government bonds. QLD fares marginally better, but still sub-optimal with cap prices averaging $\$ 8.80 / \mathrm{MWh}$ in forward trade, representing an equity return of $6.5 \%$ or 40 bps over long-bonds. 
Figure 6: Trading range for cap contracts in QLD and VIC

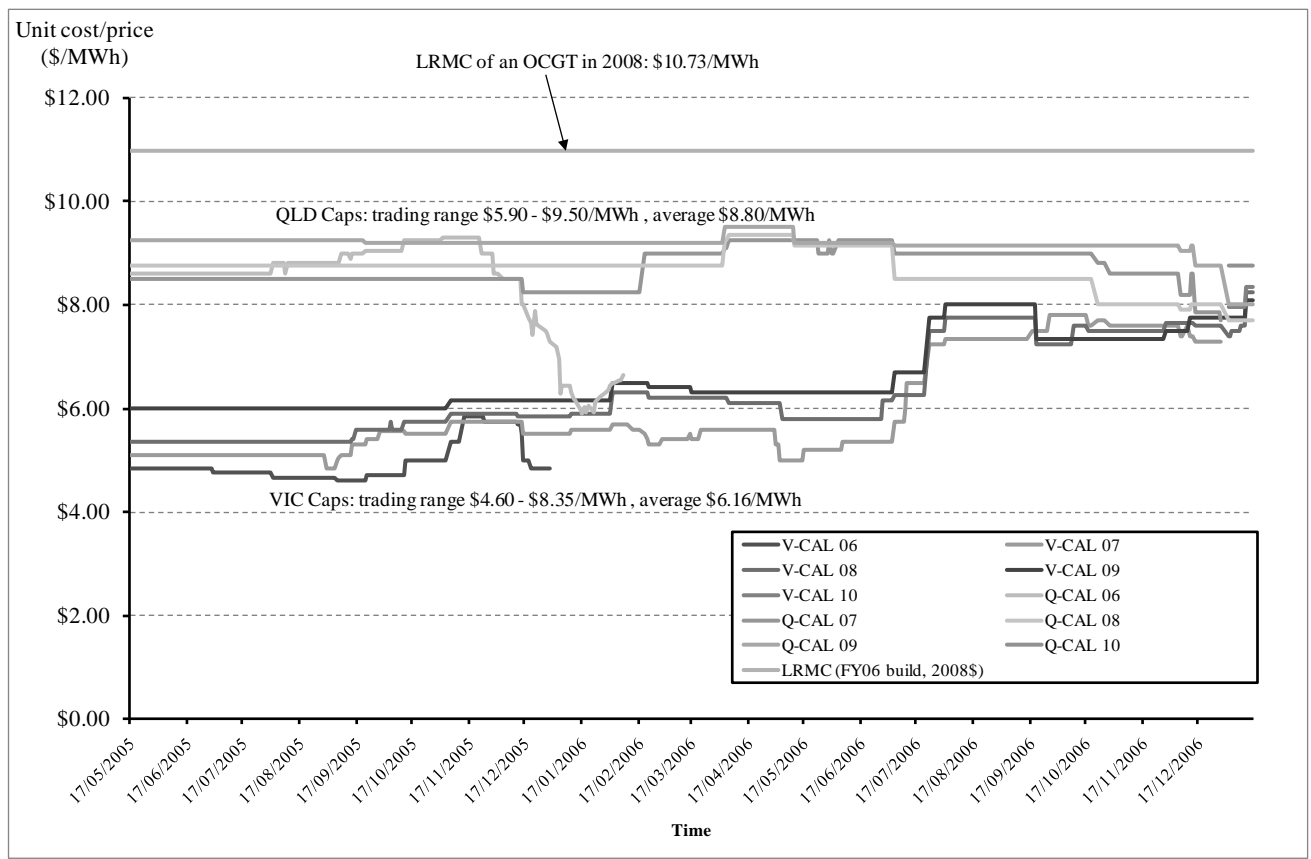

Source: ICAP, AGL Energy Ltd.

From the data presented in Figures 5 and 6, it is clear that historical spot and forward electricity prices have not provided adequate economic signals for the timely entry of plant despite looming physical shortages. This is the missing money concept in action, and the source of the Resource Adequacy problem in energy-only markets. Given the investment task confronting the electricity supply industry as highlighted in Figure 2, and the withdrawal of government owned (preemptive) investors, an obvious question arises; can an energy-only NEM design deliver capacity on-time in future? The answer is to be found in industrial organisation, and the manner in which the industry sets and regulates retail prices. To begin with, we shall examine industrial organisation, then retail pricing.

\section{The outlook for Resource Adequacy and industrial organisation}

In FY01, the NEM comprised 20+ major generators, 15 franchise retailers, none of which were VI, and six niche market retailers (ESAA, 2002). By the end of FY11, there will be less than 15 major generators, only four franchise retailers ${ }^{25}$ and five niche retailers. Most importantly, all four franchise retailers are VI merchant utilities, and all four have an investment grade credit rating ( $\geq$ BBB-) and are therefore capable of writing 'bankable' PPAs or raising corporate debt to directly invest in generating capacity. This industrial organisation and the quality of credit is in every respect a central component to stable investment patterns in the NEM.

The competition authority in Australia was initially opposed to VI. Analysis by Gans and Wolak (2008) argued that the competition authority was right to do so by demonstrating that wholesale prices increased in the NEM's post VI era via less contracting and higher resulting generator bids. However, the price benchmark they used to gauge the effect of market power was historic spot price outcomes, which bore no resemblance to entry costs (i.e. below LRMC). As demonstrated in Figures 5 and 6, there is no evidence of remunerative pricing let alone supranormal profits. In the event, the competition authority seems to have come to accept the inevitability of VI and it

${ }^{25}$ The four retailers are Origin Energy, AGL Energy, TRUenergy and Aurora Energy. Ergon Energy is technically a franchise retailer, but has no mandate to compete in the market. It operates as a retailer of last resort to uneconomic customers in regional QLD. There are other niche retailers in the NEM that have achieved VI integration but do not have an investment grade credit rating and hence are unable to provide PPAs in a manner that would satisfy project financing requirements. 
now represents the dominant thought on industrial organisation in the NEM. Indeed, Bushnell, Mansur and Saravia (2007) argue that on the contrary, VI has a moderating effect on price because forward commitments to customers are made ahead of time, thus reducing the incentive to raise wholesale price.

Horizontal consolidation and more importantly, vertical structural integration has largely followed the theory of industrial organization. When considered in light of the framework presented in Stuckey and White (1993), VI is an entirely predictable outcome in the NEM given that the market is characterised by (1) a high risk of vertical market failure, (2) high asset specificity on the supply-side, (3) bounded rationality of peaking and renewable energy contracts, and (4) price discrimination between retail and wholesale markets. These characteristics are well understood in energy-only, gross pool electricity markets, and the most important characteristics can be depicted quantitatively. Figure 7 presents NSW electricity price data from FY02 to FY09 including the monthly average spot price of electricity, the forward price of calendar year base load swaps, and the regulated retail price (i.e. the 'price to beat'). Note that the regulated retail price is measured on the right-hand-side (RHS) y-axis; the differential between the left (i.e. wholesale price) y-axis and the right (i.e. retail price) y-axis is about \$60-70/MWh. This difference essentially represents the other costs of delivered energy such as transmission and distribution network charges, retail opex, environmental market fees and other market charges.

Figure 7: Electricity prices in the NSW region (FY02 - FY09)

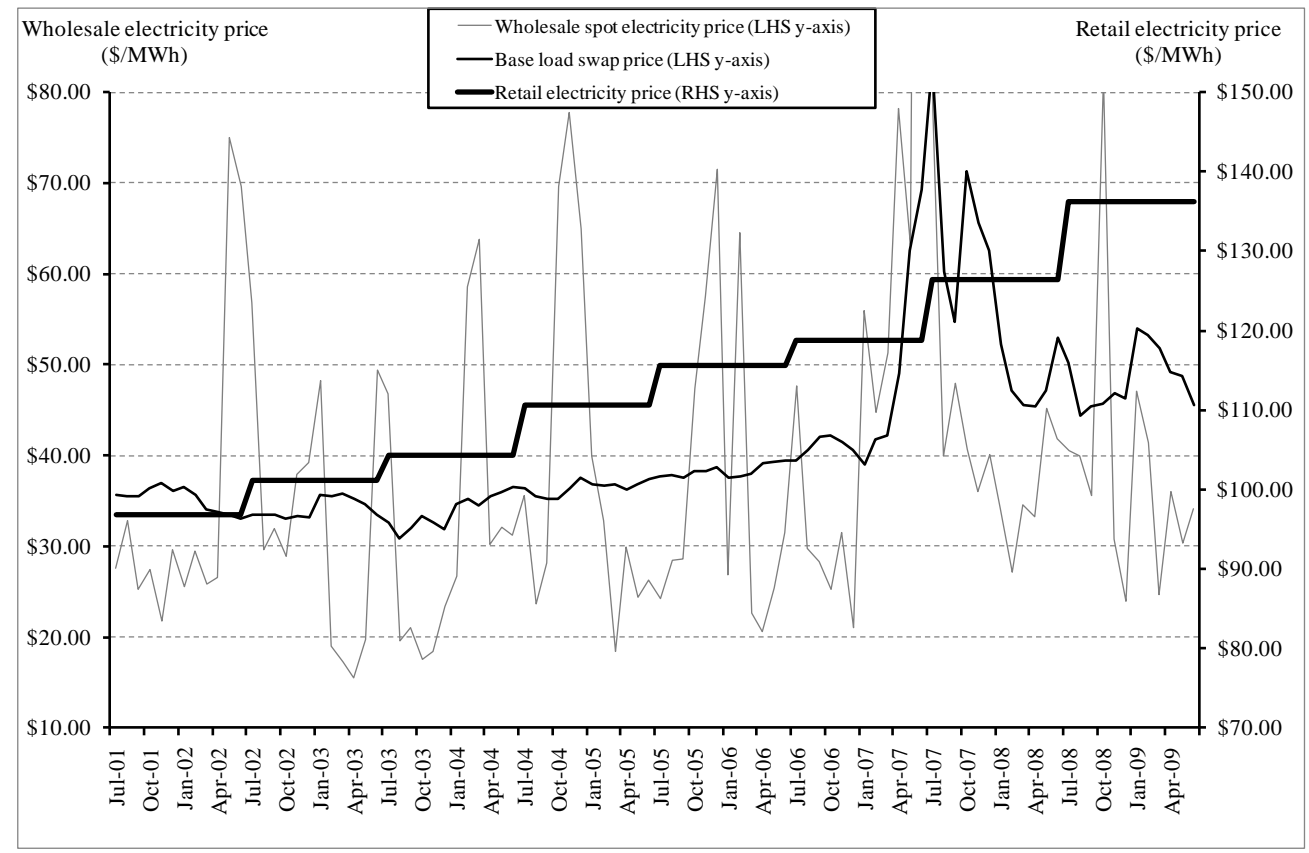

Source: AEMO, ESAA, ICAP, AGL Energy Ltd.

The relative volatility of the three NSW electricity price traces is visually apparent. Spot electricity prices are extremely volatile and as outlined earlier, could not under any circumstances be relied upon for banking a capital intensive, project-financed power station investment. Forward base hedge prices are considerably less volatile, but nonetheless are imperfect for hedging all plant types and therefore may not be relied upon for banking all new power developments either. Other hedge instruments, such as peak swaps and Caps are more volatile than base load hedge contracts due to their higher sensitivity to weather and plant outages. Regardless, liquidity beyond 3-4 years for all forms of conventional over-the-counter 
and exchange-traded hedge contracts is virtually non-existent. This makes banking of new plant virtually impossible in the absence of credit-worthy, long-dated, PPAs.

Retail prices on the other hand have historically exhibited a predictable trend. The comparison of volatility is best illustrated through coefficient of variation statistics for each price trace. The coefficient calculations for the price traces in Figure 7 are as follows:

- 0.65 for spot prices;

- 0.23 for base load swap prices; and

- 0.11 for regulated retail prices.

Average monthly spot prices are six times more volatile than retail prices, and base load swaps (the least volatile of the array of hedge instruments) are twice as volatile. But more importantly, note that retail prices move in one direction - upwards. This set of statistics forms one of the most important drivers of industrial reorganization in the NEM, and the trend-line associated with retail prices is what enables the reorganised industry to overcome the bankability hurdle facing new plant, either by way of direct investment or through writing long-dated power agreements. It is also a trend observed by the credit rating agencies. It is not entirely clear to the author whether all policy makers, regulators or even industry participants (i.e. those not close to the investment task) are aware of the fundamental nexus that has historically existed between retail prices, credit ratings and private sector investment stability. The investment and the credit rating community is, however. Consequently, the question that naturally arises from this analysis is; what is likely to happen to retail electricity prices in the future?

\section{Resource adequacy and retail price regulation}

Given the literature on Resource Adequacy, the concepts of 'missing money' and 'bankability' and the quantitative evidence presented thus far, if the NEM is to avert ill-timed investments and subsequent price shocks to consumers in the future, it will be critical that the conditions necessary for timely plant entry are present. This article has already discussed at length how industrial organization and the credit ratings of the VI merchant utilities has been critical to that end as state governments have progressively withdrawn. The remaining piece of the puzzle is the pricing policy applied by policy makers and regulators in regulated retail markets (e.g. NSW, QLD, SA), and by the firms themselves in deregulated retail markets (i.e. VIC).

It goes without saying that setting regulated retail prices as the 'price to beat' does not fit neatly with a deregulated wholesale market. The most abrupt evidence of this occurred during the Californian energy crisis in 2000. As Joskow (2001) and Bushnell (2004) noted; two of the largest investor-owned utilities in the US went from business-as-usual to bankruptcy within the space of about nine months because regulated prices, set as the price to beat, did not keep pace with rapidly rising wholesale costs. In the NEM, one niche retailer collapsed in NSW during 2007 and another in 2009; a brief review of the wholesale prices in Figure 7 very clearly demonstrates how this occurred.

Retail prices are completely deregulated in VIC and it has since been rated as the most competitive energy market in the world for two years running. ${ }^{26}$ All retail consumers of electricity in the other NEM states (i.e. QLD, NSW and SA) are contestable but have an ability to switch back to a regulated safety-net tariff. Despite having contestable retail markets, the presiding state governments of QLD, NSW and SA having opted to retain regulated retail prices for now, and are predictably exposed to politically painful media attention at each price determination.

${ }^{26}$ See Lewis (2008) and also Vaasaett (2010) at http://www.vaasaett.com/2010/05/victoria-sets-global-benchmark-for-customerswitching/ 
Historically, the Wholesale Energy Cost (WEC) component of the regulated retail prices in NEM regions have been determined using a blended weighting of wholesale market prices and theoretical costs of supplying the relevant load, as follows:

- the 'Market-Based WEC' component of the default tariff is derived by reference to live market data, using what is termed the prudent retailer approach to hedging. Regulators and their economic advisors will forecast a retailer's load, produce a median spot price trace and observe existing base swap, peak swap and cap contract prices and combine these variables in a manner which attempts to simulate how a prudent retailer would hedge their position. Financial allowances are made for load forecast error, volatility, working capital requirements and the inability to perfectly hedge weather-dependent customer load.

- The 'Market-Based WEC' component is often blended with an estimation of the LRMC of supplying the load, i.e. given prevailing capital costs and costs of capital, and optimising the rich combination of fixed and variable costs associated with base, intermediate and peaking plant technologies. The extent to which LRMC and the 'Market-Based WEC' is weighted varies between states, but is often a 50/50 split.

Throughout the first eight years of the NEM to FY07, while not perfect and with risks ever present, there was no obvious failing with this approach to determining the regulated safety-net price. With a market that was generally overweight base plant (per Table 1), wholesale prices exhibited comparatively low volatility and as a result, regulated prices were set at levels that were both profitable and predictable and they allowed competition to flourish in the retail market at or below the set levels. But all of that changed in FY08 when the wholesale market virtually imploded via drought-induced price shocks (see Figure 7). There are, therefore, three rather obvious difficulties with using the historical approach to determining the WEC component of regulated retail tariffs in the future:

1. If wholesale spot and forward prices extend well beyond LRMC due to price shock events, then the WEC will prove entirely inadequate because it will be weighed down by the LRMC component;

2. If forecasts of spot and forward prices used in the 50\% 'Market-Based WEC' component (i.e. estimated using the prudent retailer approach with live hedge data) reflect conditions of transient oversupply, or recent mild economic or weather conditions, the aggregate WEC will be weighed down to a point that will be at odds with that required by VI merchant utilities to underwrite timely plant entry. Given the quantitative results from Figures 5 and 6, this is clearly more than a theoretical possibility; and

3. Given the inherent bias of historical demand and prices in forecasts produced to determine the 'Market-Based WEC' component, any price shocks not forecast will result in a substantial (at least one-year) lag before such economic signals are incorporated into regulated retail prices.

In the debate to find the optimal solution, energy traders typically stress the importance of the wholesale energy cost allowance being based entirely on the 'Market-Based WEC' approach because the downside risk to trading books are substantial if wholesale prices rise sharply, as they did in FY08 (see Figure 7). Clearly in these conditions, using a 'Market-Based WEC' makes sense because in the absence of such action, hedge books will be in the red and retail margins will turn substantially negative, giving rise to material systemic risks and retailer failure, as occurred in the NEM in 2007 and again in 2009. 
But conversely, and most importantly, the consequence of importing $100 \%$ of the unit price volatility of the wholesale market into a regulated retail tariff would be directly at odds with the very means by which the NEM is now dealing with the Resource Adequacy problem.

Accordingly, power station 'developers' will therefore inevitably stress the importance of the WEC being based on LRMC calculations, because in the absence of such price predictability, the bankability of Greenfields plant becomes dramatically more complex.

With this backdrop, the emerging strategy adopted by policy makers and regulatory authorities in NSW and WA has been to ensure that if there is to be a regulated price to beat, then that price should incorporate a 'Market-Based WEC' with an LRMC floor. This has been evident with the intention of the WA Office of Energy approach to electricity price regulation in 2008 in Frontier Economics (2008), and in NSW by the Independent Pricing and Regulatory Tribunal (IPART). The most relevant to the NEM is NSW (i.e. NSW being a sub-region of the NEM), where the regulator is instructed to devise retail tariffs with the WEC being current 'wholesale market costs with an LRMC floor'. ${ }^{27}$ The application of this in NSW was recently undertaken by Frontier Economics (2009) on behalf of IPART. And at the time of writing, another region of the NEM, SA, had incorporated an 'LRMC as floor' in their pre-determination working papers.

This is an important development. ${ }^{28}$ Consider the simple scenario in which the entry cost of base plant is $\$ 38 / \mathrm{MWh}$ but the wholesale market for base load swaps falls to $\$ 33 / \mathrm{MWh}$ and the spot market to $\$ 28$, thereby reflecting the post entry environment in Figure 5.

- If the 'Market-Based WEC' component of a regulated retail price or 'price to beat' is set with an LRMC floor, then the implied base load component of the WEC would be \$38/MWh (i.e. the LRMC of new plant). Of course, if the wholesale market is trading below this, one could expect retailers to begin to discount against the 'price to beat' or lose market share. Even so, the reality is that churn in the world's most competitive electricity retail market (VIC) runs at around 20-25\%. The adjacent markets to VIC (i.e. QLD, NSW and SA) have churn rates between $13-15 \%{ }^{29}$ and rank in the top 10 competitive electricity retail markets globally (Lewis, 2008). In other words, even if wholesale market prices fall in any given year, only 13-15\% of the customer base may switch to a new discounted market contract. The remaining 'sticky' customer base would remain on their prior contracts or on the regulated tariff which would be referenced to a \$38/MWh WEC (i.e. base load component), equivalent to the LRMC of new plant.

- On the other hand, if the regulated retail 'price to beat' is stapled to the full force of wholesale market volatility, then it virtually ensures that $100 \%$ of the customer base will pay a WEC of $\$ 33 / \mathrm{MWh}$ (i.e. the base load component). In the event, retail competition can be expected to evaporate, much as it did in NSW in 2004-2007 when regulated retail prices were set in this manner, and holders of long-dated PPAs written at current entry costs are guaranteed substantial and immediate losses. ${ }^{30}$

The difference in these two scenarios should be obvious. Avoiding a system-wide 'drop' in the regulated retail 'price to beat' is important to ensure that sufficient conviction remains amongst

\footnotetext{
${ }^{27}$ For details, see http://www.ipart.nsw.gov.au/files/Terms\%20of\%20Reference\%20-

\%20Regulated\%20electricity\%20retail\%20tariffs\%20and\%20charges\%20for\%20small\%20customers\%202010-2013\%20-

\%2026\%20June\%202009\%20-\%20WEBSITE\%20DOCUMENT.PDF at pp 2-3.

${ }^{28}$ It is worth noting that regulators have tended to set prices by predicting how an efficient retailer would hedge given prevailing market conditions (i.e. an efficient price rather than a true safety-net price). In many cases, these prices were set too low with the benefit of hindsight.

${ }^{29}$ Based on FY10 churn rates in the various regions of the NEM.

${ }^{30}$ Churn rates in NSW plunged to just 5\% while the remaining contestable markets of VIC and SA were both running at $20 \%$.
} 
VI merchant utilities to write requisite long term PPAs on a timely basis. If the price to beat is capable of being driven below industry LRMC on a uniform basis by a regulator across an entire region, thus ensuring that sales receipts across a regional customer base also drop below the entry cost of plant, it is difficult to see how a VI merchant utility could justify large portfolios of PPAs without raising serious risks to their own investment grade credit rating.

And as the anonymous reviewers of earlier drafts of this article were at pains to highlight, above all this there is an obvious asymmetric risk in retail price regulation. If the 'price to beat' is set to low (which is obviously more than a theoretical possibility given the unpredictability and volatility of energy markets), incumbent retailer financial losses are immediate, and competition evaporates. Conversely, if the 'price to beat' is set high relative to the underlying market, churn begins to rise and excess rents are gradually competed away in any event.

The significance of this emerging 'LRMC as floor' policy setting is important for two reasons. First, by ensuring that LRMC forms a floor for regulated prices, there is no a priori reason why VI merchant utilities would not be prepared to write a 'balanced' portfolio of PPAs or invest directly in plant to ensure facilities are banked in a timely manner in order to avert spot price shocks to their own businesses of black and renewable energy. Providing VI firms don't congest their plant investment and contracting activities during market peaks, there is no reason to believe the large, investment-grade VI merchant entities responsible for the overwhelming majority of new plant will not ride-through cyclical downturns in the market. ${ }^{31}$ Second, this emerging policy stance being adopted represents tangible evidence that the root-cause associated with Resource Adequacy, 'bankability' and the requirement for entities to retain investment grade credit ratings to underwrite project financed new entrants, is actually well understood by the presiding policy makers and regulatory authorities in NSW, WA and in would seem, SA. This meeting of the minds, between investors, policy makers and regulators, provides the most optimal policy outcome if regulated retail prices are to remain a feature in those states.

To be sure, an 'LRMC as floor' approach is not a foolproof mechanism for dealing with the Resource Adequacy problem. It is merely another step in the right direction. At the extreme, an intensely oversupplied market will invariably see the 'competitive' retail price of electricity drop well below an LRMC 'price to beat'. But occasional cyclical results and outcomes are predictable business risks facing merchant utilities.

Conversely, where policy makers and regulatory authorities opt to deviate from this emerging theme, they place at risk the ability of the broader market to move investments through development pipelines in a timely manner and more importantly, run the risk of adversely affecting the credit ratings of the VI merchant utilities. With a backdrop of substantially deteriorated credit markets ${ }^{32}$ and a requirement for $18,000 \mathrm{MW}$ of plant over the next 10 years, this would seem to be a non-trivial issue. Such is the accountability of regulators and policy makers under regulated retail prices in a gross pool, uniform first-price, energy-only market.

\section{Policy implications and concluding remarks}

The purpose of this paper was to examine the question of Resource Adequacy in the continuously evolving, energy-only NEM. The primary objective was to examine how Resource Adequacy has been navigated thus far, and how it is likely to be navigated in the future. Historical analysis revealed three key drivers. The first was a vast oversupply of quality plant inherited at the outset.

\footnotetext{
${ }^{31}$ This is important. Note from Table 5 that a PPA written for a peaking plant in 2009 would be trading at a $40 \%$ discount to an identical contract written in 2004 even after accounting for inflationary effects.

${ }^{32}$ The syndicated project debt market tightened materially following the financial crisis. EAA (2009) noted that the number of active project banks reduced from $30+$ to less than 10, tenors for project financings declined from 10-15 year to 5-year money, and margins increased from 120bps to 350-400bps in Australia.
} 
Second was a heavy direct and indirect investment commitment, often pre-emptively, by AAArated government-owned entities representing 55\% of all new plant between 1997 and 2011F, and a surprisingly large 73\% of all new plant between 1997 and 2007. Third, albeit buried in footnote 20, was the change to the method of reserve plant calculations made by NEMMCo, which was responsible for the material shift in lack of reserve between 2003 and 2004 in Table 4.

In navigating Resource Adequacy from 2007 onwards, this article indicates that the answer is, quite simply, through industrial organisation and retail price stability. The credit ratings of the VI merchant utilities was highlighted as critical given the exit of state governments and the heightened thresholds of financiers following the financial and economic crisis in FY09.

As a gross pool, energy-only electricity market with a uniform first-price auction clearing mechanism, the NEM is noted for its success in driving static productive efficiency. But in Section 4 the quantitative evidence confirmed that entry costs, lack of reserve, and forward hedge prices did not link-up in a way that conventional microeconomic theory might otherwise suggest. Thus is Cramton and Stoft's (2006) missing money concept in action.

On regulated prices, an emerging response from policy makers and regulatory authorities has been to ensure that the conditions facing the reorganized and vertically-integrated industry favour investment and the 'banking' of new projects, which in the context of a forecast investment requirement of 18,000MW to 2020 and the political economy of electricity, is hard to fault. And crucially, if Resource Adequacy is to be navigated, the presence of investment grade VI merchant utilities is quite fundamental; in the absence of such entities writing PPAs, the project financing of new power plants in the current economic climate at least borders on the impossible regardless of what industry fundamentals might otherwise imply. This is a key example of where the principles of economic theory and the practical realities of corporate finance quite simply collide.

A key emerging policy objective in relation to retail price regulation has been to ensure that regardless of where the shorter-term spot and forward markets are trading, the price to beat should be set with an LRMC floor, thus ensuring that longer-dated price signals exists in the NEM; one that does not import all of the volatility of the spot and forward markets. The practical experience from the fully deregulated VIC market certainly reflects industry-LRMC pricing.

Regardless, given that state governments have now exited the investment market in the NEM, in any future decision on retail pricing or energy policy more generally, regulators and policy makers must introduce an additional item into their assessment criteria; 'what does this change do to the credit ratings of those who will underwrite our next power station?'

\section{References}

ACIL Tasman (2009), "Fuel resource, new entry and generation costs in the NEM", ACIL Tasman Publication, Melbourne. Available at www.aemo.com.au. Accessed 22 November 2009.

APRA: Australian Prudential Regulatory Authority, (2007), “APRA Insight - 10 years of superannuation data collection: 1996 to 2006”, APRA Publication, Sydney.

Besser, J., Farr, J. and Tierney, S. (2002), "The political economy of long-term generation adequacy: why an ICAP mechanism is needed as part of standard market design”, Electricity Journal, 15(7): 53-62.

Bidwell, M. and Henney, A. (2004), “Will Neta ensure generation adequacy?”, Power UK, Issue 122, April 2004.

Bushnell, J. (2004), “California’s electricity crisis: a market apart?”, Energy Policy, 32(9): 1045-1052. 
Bushnell, J. (2005), “Electricity Resource Adequacy: matching policies and goals”, Electricity Journal, 18(8): 11-21.

Bushnell, J., Mansur, E. and Saravia, C. (2007), "Vertical arrangements, market structure and competition: an analysis of restructured US electricity markets”, American Economic Review, 98(1): 237-266.

Cramton, P. and Stoft, S. (2006), "The convergence of market designs for adequate generating capacity with special attention to the CAISO's Resource Adequacy problem”, Center for Energy and Environmental Policy Research Working Paper 06-007. Available at http://stoft.com/p/50.html

de Vries, L. (2002), "Securing the public interest in electricity generation markets, the myths of the invisible hand and the copper plate”, PhD Dissertation, Delft University of Technology, The Netherlands.

de Vries, L. And Hakvoort, R. (2004), "The question of generation adequacy in liberalised electricity markets”, Centre for European Policy Studies, INDES Working Papers No.5. Available at www.ceps.be

de Vries, L. And Heijnen, P. (2007), "The impact of electricity market design upon investment under uncertainty: the effectiveness of capacity mechanisms”, Utilities Policy, 16(2008): 215-227.

Dixit, A. and Pindyck, R. (1994), Investment Under Uncertainty, Princeton University Press, Princeton New Jersey, Ch. 2-5.

Doorman, G. "Peaking capacity in restructured power systems", PhD Dissertation, Norwegian University of Science and Technology, available at http://ntnu.divaportal.org/smash/record.jsf?searchId=1\&pid=diva2:125349\&rvn=3

EAA: Energy Alliance of Australia, (2009), “Financing the Australian Energy Sector 2009”, EAA Publication, Sydney.

ESAA: Energy Supply Association of Australia, (2002), Electricity Australia, ESAA Publication, Melbourne.

ESAA: Energy Supply Association of Australia, (2009), ElectricityGas Australia, ESAA Publication, Melbourne.

Finon, D. (2008), "Investment risk allocation in decentralised markets: the need of long-term contracts and vertical integration”, OPEC Energy Review, 32(2): 150-183.

French, J. (2003), 'Australian Gas Light Company v Australian Competition and Consumer Commission (No 3)', FCA 1525.

Frontier Economics (2008), "Electricity retail market review - electricity tariffs: draft recommendations prepared for the Western Australian Office of Energy”, April 2008, Frontier Economics, Melbourne. Available from www.energy.wa.gov.au Accessed 10 November 2009.

Frontier Economics (2009), “Modelling methodology and assumptions - a report for IPART”, August 2009, Frontier Economics, Melbourne. Available from www.ipart.nsw.gov.au.

Gas, J. And Wolak, F. (2008), “A comparison of ex ante versus ex post vertical market power: evidence from the electricity supply industry”, Available at http://papers.ssrn.com/sol3/papers.cfm?abstract_id=1288245

Hogan, W. (2005), “On an 'energy only’ electricity market design for resource adequacy”, Centre for Business and Government, John F Kennedy School of Government, Harvard University, Cambridge.

IEA: International Energy Agency, (2005), "Energy Policies of IEA Countries - Australia 2005 Review”, IEA Publication, Paris. Available at http://www.iea.org/textbase/nppdf/free/2005/australia2005.pdf 
IES: Intelligent Energy Systems (2009), “Wind energy - how much is enough?”, Insider, Issue 010, November, pp.1-9.

Joskow, P. (2001), “California’s electricity crisis”, Oxford Review of Economic Policy, 17(3): 365-389.

Joskow, P. (2006), “Competitive electricity markets and investment in new generating capacity”, Center for Energy and Environmental Policy Research Working Paper 06-009.

Lewis, P. (2008), "World energy retail market rankings $4^{\text {th }}$ edition- utility customer switching research project”, Vaasaett Publication, Available at http://www.vaasaett.com/. Accessed 10 November 2009.

NEMMCo: National Electricity Market Management Company (2003-2005), "Statement of Opportunities”, NEMMCo Publication, Melbourne.

Neuhoff, K. and De Vries, L. (2004), “Insufficient incentives for investment in electricity generation”, CMI Working Paper 42, Cambridge.

Newbery, D. (2006), “Market Design”, EPRG Working Paper No. 0515, University of Cambridge. Available at http://www.eprg.group.cam.ac.uk/category/publications/working-paper-series

Orchison, K. (2010), "Distance cuts down the options”, The Australian - Climate Change Special Report, Thursday 4 March, p.4.

Oren, S. (2003), “Ensuring generation adequacy in competitive electricity markets”, University of California Energy Institute - Energy Policy \& Economics 007, University of California, Berkley.

Owen, A. (2007), "Inquiry into electricity supply in NSW”, NSW Government Publication, Sydney.

Peluchon, B. (2003), “Is investment in peak generation assets efficient in a deregulated electricity sector?”, Research Symposium: European Electricity Markets, The Hague, September 2003.

Roques, F., Newbery, D. and Nuttall, W. (2005), “Investment incentives and electricity market design: the British experience”, Review of Network Economics, 4(2): 93-127.

Simshauser, P. (2001), “Excess entry in the deregulated QLD power market”, Economic Analysis and Policy, 31(1): 73-92.

Simshauser, P. (2005), "The gains from the microeconomic reform of the power generation industry in east-coast Australia”, Economic Analysis and Policy, 35(1\&2): 23-43.

Simshauser, P. (2008), "The dynamic efficiency gains from introducing capacity payments in the national electricity market”, Australian Economic Review, 41(4): 349-370.

Simshauser, P. (2009), “On emissions trading, toxic debt and the Australian power market”, Electricity Journal, 22(2): 9-29.

Simshauser, P. (2010), "Resource adequacy, capital adequacy and investment uncertainty in the Australian power market”, Electricity Journal, 23(1): 67-84.

Simshauser, P., Molyneux, E. and Shepherd, M. (2010), “The entry cost shock and the re-rating of power prices in NSW", Australian Economic Review, 43(2): 114-135.

Simshauser, P. and Wild, P. (2009), “The Western Australian power dilemma”, Australian Economic Papers, 48(4): 342-369.

Smith, C. and Warner, J. (1979), “On financial contracting - an analysis of bond covenants”, Journal of Financial Economics, 7(1979): 117-161. 
Stoft, S. (2002), Power System Economics: Designing Markets for Electricity, Piscataway, IEEE Press, New Jersey.

Stuckey, J. And White, D. (1993), "When and when not to vertically integrate”, MIT Sloan Management Review, 34(3): 71-83.

Wen, F., Wu, F. and Ni, Y. (2004), "Generation capacity adequacy in the competitive electricity market environment”, Electrical Power \& Energy Systems, 26(2004): 365-372.

Vazquez, C., Rivier, M. And Perez-Arriaga, I. (2002), “A market approach to long-term security of supply”, IEEE Transactions on Power Systems, 17(2): 349-357.

Von der Fehr, N-H. and Harbord, D. (1995), "Capacity investment and long-run efficiency in market-based electricity industries", in Olsen, O., Competition in the electricity supply industry - experience from Europe and the United States, DJ0F Publishing, Copenhagen. 
Appendix I: NEM private sector incumbents and all new entrants to 2011F

\begin{tabular}{|c|c|c|c|c|c|c|c|}
\hline Plant & Region & Current Owner & Technology & Original Financing & Year & $\begin{array}{r}\text { Capacity } \\
\text { (MW) }\end{array}$ & Revenue Source \\
\hline \multicolumn{8}{|c|}{ EXISTING PLANT PRIVATISED IN THE 1990’s } \\
\hline West Kiewa & VIC & AGL & Hydro & Project Finance & 1990’s & 62 & Vesting Contract \\
\hline Eildon & VIC & AGL & Hydro & Project Finance & 1990’s & 135 & Vesting Contract \\
\hline Dartmouth & VIC & AGL & Hydro & Project Finance & 1990’s & 150 & Vesting Contract \\
\hline Playford & SA & $\mathrm{BBP}$ & Brown coal & Project Finance & 1990’s & 240 & Vesting Contract \\
\hline Hazelwood & VIC & IP & Brown coal & Project Finance & 1990’s & 1,600 & Vesting Contract \\
\hline Dry Creek & SA & IP & OCGT & Project Finance & 1990’s & 156 & Vesting Contract \\
\hline Yallourn W & VIC & TRUenergy & Brown coal & Project Finance & 1990’s & 1,480 & Vesting Contract \\
\hline Torrens Island & SA & AGL & Gas/Steam & Project Finance & 1990’s & 1,280 & Vesting Contract \\
\hline Newport & VIC & IFM & Gas/Steam & Project Finance & 1990’s & 510 & VI PPA \\
\hline McKay Creek & VIC & AGL & Hydro & Project Finance & 1990’s & 150 & Vesting Contract \\
\hline Jeeralang A\&B & VIC & IFM & OCGT & Project Finance & 1990’s & 449 & VI PPA \\
\hline Gladstone & QLD & NRG & Black coal & Project Finance & 1990’s & 1,680 & Govt PPA \\
\hline Mintaro & SA & IP & GT & Project Finance & 1990’s & 90 & Vesting Contract \\
\hline Northern & SA & BBP & Brown coal & Project Finance & 1990’s & 540 & Vesting Contract \\
\hline Loy Yang A & VIC & GEAC & Brown coal & Project Finance & 1990’s & 2,120 & Vesting Contract \\
\hline Loy Yang B & VIC & IP/Mitsui & Brown coal & Project Finance & 1990’s & 1,000 & Govt PPA \\
\hline Barcaldine & QLD & Ergon & CCGT & Project Finance & 1990’s & 57 & Govt PPA \\
\hline \multicolumn{4}{|c|}{ Total Existing Plant } & & & 11,699 & \\
\hline \multicolumn{8}{|c|}{ NEW DEVELOPMENTS } \\
\hline Smithfield & NSW & Marubeni & CCGT & Project Finance & 1997 & 160 & Govt PPA \\
\hline Mt Stuart & QLD & Origin & OCGT & Corporate Facility & 1998 & 304 & Govt PPA \\
\hline Collinsville & QLD & TSI & Black coal & Project Finance & 1998 & 180 & Govt PPA \\
\hline Osborne & SA & ACTO Power & CCGT & Project Finance & 1998 & 185 & Govt PPA \\
\hline Roma & QLD & Origin & OCGT & Corporate Facility & 1999 & 80 & Merchant \\
\hline Oakey & QLD & $\mathrm{OPH}$ & OCGT & Project Finance & 2000 & 288 & Govt PPA \\
\hline Pelican Point & SA & IP & CCGT & Project Finance & 2000 & 478 & Vesting Contract \\
\hline Ladbroke Grove & SA & Origin & OCGT & Corporate Facility & 2000 & 84 & VI \\
\hline Port Lincoln & SA & IP & OCGT & Project Finance & 2000 & 50 & Merchant \\
\hline Redbank & NSW & $\mathrm{BBP}$ & Black coal & Project Finance & 2001 & 150 & Govt PPA \\
\hline Bairnsdale & VIC & $\mathrm{BBP}$ & OCGT & Project Finance & 2001 & 92 & PPA \\
\hline Callide C & QLD & CS Energy & Black coal & Project Finance & 2001 & 900 & Govt/Merchant \\
\hline Somerton & VIC & AGL & OCGT & Corporate Facility & 2002 & 160 & VI \\
\hline Millmerran & QLD & InterGen & Black coal & Project Finance & 2002 & 852 & Merchant \\
\hline Hallett & SA & TRUenergy & OCGT & Corporate Facility & 2002 & 183 & VI \\
\hline Quarantine & SA & Origin & OCGT & Corporate Facility & 2002 & 92 & VI \\
\hline Valley Power & VIC & Snowy Hydro & OCGT & Project Finance & 2002 & 300 & Govt/VI PPA \\
\hline Tarong North & QLD & Tarong Energy & Black coal & Project Finance & 2002 & 443 & Govt/Merchant \\
\hline Swanbank E & QLD & CS Energy & CCGT & Government & 2002 & 385 & Govt/Merchant \\
\hline Yabulu & QLD & TSI & CCGT & Project Finance & 2005 & 240 & Govt/PPA \\
\hline Angaston & SA & Infratil & RecipEng & Project Finance & 2005 & 50 & VI PPA \\
\hline Braemar & QLD & $\mathrm{BBP}$ & OCGT & Project Finance & 2006 & 504 & Govt PPA \\
\hline Laverton & VIC & Snowy Hydro & OCGT & Government & 2006 & 320 & Govt/Merchant \\
\hline Kogan Creek & QLD & CS Energy & Black coal & Government & 2007 & 750 & Govt/Merchant \\
\hline Tallawarra & NSW & TRUenergy & CCGT & Corporate Facility & 2009 & 482 & VI \\
\hline Uranquinty & NSW & Origin & OCGT & Project Finance & 2009 & 600 & VI \\
\hline Bogong & VIC & AGL & Hydro & Corporate Facility & 2009 & 140 & VI \\
\hline Braemer II & QLD & Arrow/ERM & OCGT & Project Finance & 2009 & 450 & VI PPA \\
\hline Condamine & QLD & QGC/ANZIS & CCGT & Project Finance & 2009 & 140 & VI PPA \\
\hline Mt Stuart II & QLD & Origin & OCGT & Corporate Facility & 2009 & 126 & VI \\
\hline Tamar & TAS & Aurora & CCGT & Corporate Facility & 2009 & 210 & Govt PPA \\
\hline Tamar & TAS & Aurora & OCGT & Corporate Facility & 2009 & 60 & Govt PPA \\
\hline Darling Downs & QLD & Origin & CCGT & Corporate Facility & 2010 & 630 & VI \\
\hline Colongra & NSW & Delta Electricity & OCGT & Government & 2010 & 600 & Govt/Merchant \\
\hline Mortlake & VIC & Origin & OCGT & Corporate Facility & 2011 & 550 & VI \\
\hline \multicolumn{6}{|c|}{ Total New Developments } & 11,341 & \\
\hline
\end{tabular}

